\title{
Adsorption kinetics of herbicide paraquat in aqueous solution onto a low-cost adsorbent, swine-manure-derived biochar
}

\author{
W. -T. Tsai $\cdot$ H. -R. Chen
}

Received: 20 January 2012/Revised: 9 August 2012/ Accepted: 30 December 2012/Published online: 8 February 2013

(C) Islamic Azad University (IAU) 2013

\begin{abstract}
Biochars have received increasing attention in recent years because of their significant properties such as carbon sequestration, soil fertility, and contaminant immobilization. In this work, the adsorptive removal of paraquat $\left(1,1^{\prime}\right.$-dimethyl-4,4'-dipyridinium chloride, one of the most widely used herbicides) from aqueous solution onto the swine-manure-derived biochar has been studied at $25^{\circ} \mathrm{C}$ in a batch adsorption system. The adsorption rate has been investigated under the controlled process parameters including initial $\mathrm{pH}$ (i.e., 4.5, 6.0, 7.5, and 9.0), paraquat concentration (i.e., $0.5,1.0,2.0,4.0$, and $6.0 \mathrm{mg} / \mathrm{L}$ ), and biochar dosage (i.e., $0.10,0.15,0.20,0.25$, and $0.30 \mathrm{~g} / \mathrm{L}$ ). Based on the adsorption affinity between cationic paraquat and carbon-like adsorbent, a pseudo-second order model has been developed using experimental data to predict the adsorption kinetic constant and equilibrium adsorption capacity. The results showed that the adsorption process could be satisfactorily described with the reaction model and were reasonably explained by assuming an adsorption mechanism in the ion exchange process. Overall, the results from this study demonstrated that the biomassderived char can be used as a low-cost adsorbent for the removal of environmental cationic organic pollutants from the water environment.
\end{abstract}

Keywords Liquid-phase adsorption - Paraquat . Swine manure $\cdot$ Biochar $\cdot$ Kinetic modeling

W.-T. Tsai $(\bowtie) \cdot$ H.-R. Chen

Graduate Institute of Bioresources, National Pingtung University of Science and Technology, Pingtung 912, Taiwan, China e-mail: wttsai@mail.npust.edu.tw

\section{Introduction}

In response to the global environmental issues (i.e., global warming and acid rain), the resource supply from domestic biomass has received much attention in recent years. In this regard, renewable wastes such as agricultural residues, bioprocessing wastes, and animal wastes are increasingly being recognized as valuable bioresources for producing biofuels and chemicals because they are rich in carbon sources (Blaschek et al. 2010). More importantly, the biomass-derived char (also called biochar), one of the carbon-rich materials produced under an inert atmosphere and at relatively low carbonization temperature, can be applied to the soil as a means of improving soil productivity and fertility, carbon storage and sequestration, mitigation of nitrous oxide $\left(\mathrm{N}_{2} \mathrm{O}\right)$ emissions, filtration of percolating soil water, and its dissolved pollutants (Lehannes and Joseph 2009). As a consequence, one of the most important properties for biochar is its high affinity and potential for adsorbing agrochemicals and contaminants such as herbicides and insecticides. Therefore, the addition of biochar to soil as an amendment would be expected to enhance the adsorption or sorption properties of the soil and, hence, have a significant effect on the environmental fate and ecotoxicological impacts of organic compounds present in that soil.

Animal manures often contain large amounts of moisture, pathogens, and organic carbon and nitrogen. As a result, these poultry and livestock manures may pose a threat to the public health and environmental quality because of the potential contamination of water bodies (e.g., surface water and groundwater) and ambient air via discharging and disposing off from farm sites, and odor releases. Traditionally, composting as a waste management option or recycling directly into farmland for animal 
manure as fertilizer supplement has been widely adopted to promote the plant growth in agronomy and horticulture (Qian et al. 2008). It should be noted that a large proportion of the carbon and nitrogen in manure could be directly and indirectly returned as carbon dioxide $\left(\mathrm{CO}_{2}\right)$, methane $\left(\mathrm{CH}_{4}\right)$, and nitrous oxide $\left(\mathrm{N}_{2} \mathrm{O}\right)$ from the manure waste management systems (IPCC 2006). Thus, there is an increasing interest in converting dried swine manure into valuable products (i.e., heat, biofuels, and biochar) via thermochemical processes over the past decade (He et al. 2000a, b; Priyadarsan et al. 2004; Ro et al. 2007, 2009; Zhang et al. 2009; Ro et al. 2010).

Organic pesticide residues have been reported in drinking water, agricultural water, and groundwater (Fernandez et al. 1998; Ritter et al. 2002). These pesticides generally penetrate into surface water in runoff from land applications (Khan 1980). The mobility of pesticide left in soil, on the other hand, generally enters groundwater via leaching. Paraquat $\left(1,1^{\prime}\right.$-dimethyl-4,4'-dipyridinium chloride), also known as methyl viologen, is frequently used as a quaternary ammonium and nonselective contact herbicide on weeds and grasses in agricultural and nonagricultural areas due to its excellent action within the plant cells (Lock and Wilks 2010). However, it is known that this compound (WHO Class II, moderately hazardous) is one of the most toxic poisons. In Taiwan, the maximum discharge concentration of paraquat has been set at $0.1 \mathrm{mg} / \mathrm{L}$ according to the effluent standards. Consequently, it is important to study both the adsorption effectiveness and environmental fate of cationic paraquat with porous solids (e.g., biochar) from the viewpoints of mobility in the soil medium and/or methods of control in the adsorption process.

For virtually all pesticides, carbon adsorption has been considered as the best available technology for the removal of organic residues in water and wastewater (Brady and McGay 1996). However, an important feature of cationic paraquat is to adsorb strongly on clay minerals, and somewhat less on activated carbon due to its highly polar nature of expanding lattice clay, like montmorillonite (de Keizer 1990). Given the similarities in some of the properties of carbon-rich materials including coal, char, charcoal, biochar, and activated carbon, a few studies on adsorptive removal of paraquat have been reported in the literature. Parkash (1974) investigated the adsorption of cationic paraquat from aqueous solution onto three activated carbons with variations in surface area, suggesting that the adsorption rate limiting step should be characterized by intraparticle transport of the pesticide solute in the micropores of the carbon adsorbent. MacCarthy and Djebbar (1986) pointed out that acid-activated peat with concentrated sulfuric acid at elevated temperature could be used as an effective adsorbent for removal of paraquat from the aqueous solution due to the enhanced cation-exchange capacity. Hamadi et al. (2004) studied the adsorption of paraquat from aqueous solution by activated carbon derived from used tires. The effects of particle size, carbon dosage, temperature, and initial paraquat concentration on the adsorption rate were studied. It was found that the adsorption rate of paraquat onto the carbon adsorbent is very fast, and the pseudo-second-order reaction model thus appears to be the best correlation. Sannino et al. (2008) examined the sorption of paraquat using polymerin, the humic acid-like polymer from olive oil mill wastewater. They studied the effects of initial concentration, $\mathrm{pH}$, contact time, and sorbent dosage on the sorption of herbicide, showing that the sorption mechanism of paraquat on polymerin was consistent with the ion exchange of this herbicide with $\mathrm{Ca}, \mathrm{Mg}$, and $\mathrm{K}$ natively occurring in the sorbent.

In the previous studies (Tsai et al. 2002a, b, 2003a, b, 2004), it was found that a rapid decrease in residual paraquat concentration occurred according to the adsorption kinetics using activated bleaching earth or activated clay. With respect to the kinetics and its modeling of paraquat adsorption onto biochar from the aqueous solution, the existing body of the literature is very limited. However, the study on the effects on the sorption fate process of paraquat can help better understand the likely environmental and agronomic consequences of biochar amendments on soil. Thus, the present study aimed at providing one option for utilizing the swine-manurederived biochar in the soil amendment applications and determining the potential mobility of the toxic compound in the water environment. The main objectives of this work were to determine the extent of the effects of initial $\mathrm{pH}$, paraquat concentration, and biochar dosage at paraquat adsorption rate in an agitated non-flow system, and also evaluate the usefulness of the most used adsorption model (i.e., pseudo-second-order) for analyzing the adsorption system.

\section{Materials and methods}

\section{Materials}

The adsorbate used in the adsorption experiments is paraquat with purity of minimum $98 \%$, which was purchased from ACROS Organics Co. (Belgium). The molecular sizes of paraquat are about $1.34 \mathrm{~nm} \times 0.36 \mathrm{~nm}$ (Draoui et al. 1999). Its chemical formula and molecular weight are $\mathrm{C}_{12} \mathrm{H}_{14} \mathrm{Cl}_{2} \mathrm{~N}_{2}$ and $257.16 \mathrm{~g} / \mathrm{mol}$, respectively. The biochar adsorbent was prepared from the pyrolysis of the swine manure sample in a vertically fixed-bed reactor as reported similarly (Tsai et al. 1997, 1998). The experimental conditions in the pyrolysis system were performed at the fixed 
heating rate of about $10 \mathrm{~K} / \mathrm{min}$ up to the prescribed temperature (i.e., $673 \mathrm{~K}$ ), and then held for $1 \mathrm{~h}$ before cooling to room temperature. The resulting biochar product was taken from holder to weigh its mass, and then stored in the desiccator for its chemical and physical characterization, including approximate analysis, ultimate analysis (using elemental analyzer), inorganic elemental analysis (using inductively coupled plasma-atomic emission spectrometer), surface area and pore volume (using surface area and porosity analyzer), and true density (using pycnometer). $\mathrm{H}_{2} \mathrm{SO}_{4}$ and $\mathrm{NaOH}$ with purity of minimum 97.0 and $98.0 \%$, respectively, used for adjusting initial $\mathrm{pH}$ value in aqueous solutions to obtain the extent of the adsorption capacity of paraquat onto the biochar, were purchased from Merck Co. (Germany). On the other hand, one commercial activated carbon (denoted as BPL; BET surface area $\fallingdotseq$ $1,000 \mathrm{~m}^{2} / \mathrm{g}$ ), purchased from Calgon Carbon (Pittsburgh, USA), was used as a comparative adsorbent because it has been the most widely used adsorbent for organic pollutants.

Table 1 listed the chemical and physical (pore) properties of the swine-manure-derived biochar. The resulting biochar sample displayed a high adsorption potential towards probe molecule (i.e., nitrogen) at the very low values of relative pressure $\left(P / P_{0}\right)$ from 0 to about 0.05 from the $\mathrm{N}_{2}$ adsorption-desorption isotherm (not shown), which is characteristic of microporous solid, but has a relatively low surface area. This was in agreement with the micropore surface area (i.e., $2.757 \mathrm{~m}^{2} / \mathrm{g}$ ) compared to the BET surface area (i.e., $5.721 \mathrm{~m}^{2} / \mathrm{g}$ ) of the biochar in Table 1 . Figure 1 showed its images of scanning electron microscope (SEM) and energy dispersive X-ray spectroscopy (EDS). The porous structure examination of the resulting biochar can be clearly seen in the SEM photograph. Also shown in Fig. 1, the EDS spectrum on the surface of the resulting biochar identified the major elements (including carbon, oxygen, calcium, phosphorus, magnesium, and potassium), which were consistent with those by the ultimate analysis and inorganic element analysis, as listed in Table 1.

\section{Adsorption kinetics}

All the experiments of adsorption kinetics were carried out in a ca. 3-L stirred batch adsorber with four baffles as similarly described in the previous studies (Tsai et al. 2003a, b, 2004). The adsorber was immersed in a refrigerated circulating-water bath for isothermal conditioning (i.e., $25{ }^{\circ} \mathrm{C}$ ) prior to the experiment. Preliminary investigations on the adsorption rate using the biochar adsorbent have indicated that the process occurred rapidly. After the lapse of 60-120 min, a gradual approach to the adsorption capacity was observed. The effect of agitation speeds at 120 and $360 \mathrm{rpm}$ on paraquat adsorption seemed to be
Table 1 Chemical and pore properties of the swine-manure-derived biochar

\begin{tabular}{|c|c|}
\hline Chemical property & Value $^{\mathrm{c}}$ \\
\hline \multicolumn{2}{|l|}{ Proximate analysis } \\
\hline Moisture (wt \%) & $2.93 \pm 0.44$ \\
\hline Ash (wt \%) & $43.53 \pm 0.74$ \\
\hline Combustible $^{\mathrm{a}}$ (wt \%) & 53.54 \\
\hline \multicolumn{2}{|l|}{ Ultimate analysis ${ }^{\mathrm{b}}$} \\
\hline Carbon (wt \%) & $41.80 \pm 0.04$ \\
\hline Hydrogen (wt \%) & $0.95 \pm 0.01$ \\
\hline Oxygen (wt \%) & $20.64 \pm 0.08$ \\
\hline Nitrogen (wt \%) & $3.16 \pm 0.06$ \\
\hline Sulfur (wt \%) & $0.00 \pm 0.00$ \\
\hline \multicolumn{2}{|l|}{ Inorganic element analysis ${ }^{b}$} \\
\hline Calcium $(\mathrm{Ca})$ & $5.49 \pm 0.07$ \\
\hline Phosphorus (P) & $6.05 \pm 0.05$ \\
\hline Magnesium (Mg) & $3.00 \pm 0.01$ \\
\hline Potassium (K) & $3.10 \pm 0.07$ \\
\hline Zinc (Zn) & $0.205 \pm 0.020$ \\
\hline Manganese (Mn) & $0.159 \pm 0.000$ \\
\hline Copper $(\mathrm{Cu})$ & $0.045 \pm 0.001$ \\
\hline Pore property & Value \\
\hline BET surface area & $5.721 \mathrm{~m}^{2} / \mathrm{g}$ \\
\hline Microporous surface area ${ }^{\mathrm{d}}$ & $2.757 \mathrm{~m}^{2} / \mathrm{g}$ \\
\hline Total pore volume & $0.0153 \mathrm{~cm}^{3} / \mathrm{g}$ \\
\hline Microporous pore volume ${ }^{\mathrm{d}}$ & $0.00134 \mathrm{~cm}^{3} / \mathrm{g}$ \\
\hline Average pore width ${ }^{\mathrm{e}}$ & $10.71 \mathrm{~nm}$ \\
\hline Particle density ${ }^{\mathrm{f}}$ & $1.775 \mathrm{~g} / \mathrm{cm}^{3}$ \\
\hline True density ${ }^{\mathrm{g}}$ & $1.825 \mathrm{~g} / \mathrm{cm}^{3}$ \\
\hline Porosity $^{\mathrm{h}}$ & 0.027 \\
\hline
\end{tabular}

\footnotetext{
${ }^{a}$ By difference

b Dry basis (by heating at $383 \mathrm{~K}$ for $24 \mathrm{~h}$ )

c Average \pm standard deviation (for two/three measurements)

d Obtained from the $t$-plot method

e Estimated by the values of BET surface area and total pore volume, which were obtained by an ASAP 2020 apparatus (Micromertics Co., USA)

${ }^{\mathrm{f}}$ Estimated by the values of total pore volume and true density

$\mathrm{g}$ Measured by the helium-displacement method using an AccuPyc 1340 pycnometer (Micromeritics Co., U.S.A.)

${ }^{\mathrm{h}}$ Calculated from the values of particle density and true density
}

negligible, as shown in Fig. 2. This result could be explained from the fact that the strong turbulence and the very small thickness around the adsorbent particles in the boundary layer occurred at the agitation speeds ranging from 120 to $360 \mathrm{rpm}$ and induced a significant reduction in the boundary layer resistance. Thus, each sample of the solution (ca. $15 \mathrm{~mL}$ ) was withdrawn from the adsorber with the agitation speed of $120 \mathrm{rpm}$, using a $20 \mathrm{~mL}$ syringe at intervals of 2.5, 5.0, 10.0, 20.0, 40.0, 60.0, and $80.0 \mathrm{~min}$. 

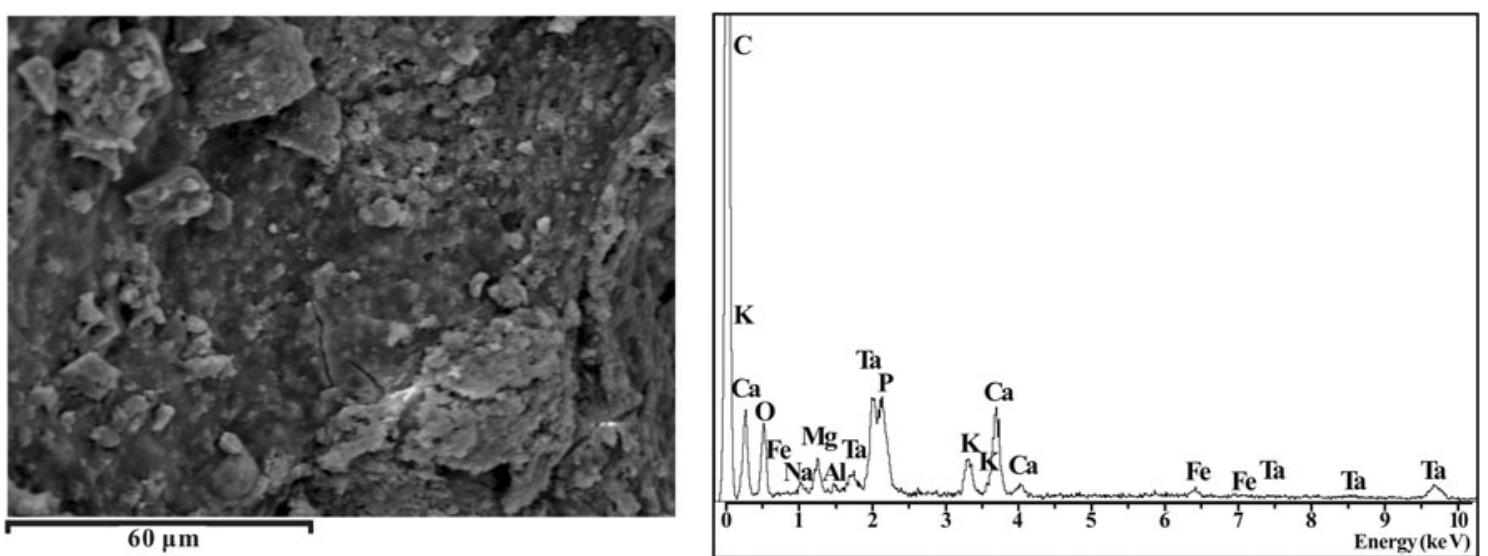

Fig. 1 SEM images $(l e f t ; \times 1,000)$ and corresponding EDS spectra $(r i g h t)$ of the swine-manure-derived biochar

It was then filtrated with a mixed cellulose esters (MCE) membrane (pore size: $0.45 \mu \mathrm{m}$; filter size: $25 \mathrm{~mm}$ (Dia.); Cat. No.: MJM 4525; Chrom Tech Co., Taiwan). The analyses of paraquat concentration in the filtrate solution after adding sodium dithionite (MERCK Co., Germany; purity of minimum $87.0 \%$ ) were immediately made with a $1.0 \mathrm{~cm}$ light path quartz cell in a spectrophotometer (Hitachi U-2900) at $\lambda_{\max }$ of $600 \mathrm{~nm}$ based on the AOAC Official Method 969.09. The amount of paraquat adsorbed was determined as follow:

$q_{\mathrm{t}}=\left(C_{\mathrm{o}}-C_{\mathrm{t}}\right) \cdot V / W$

where $C_{\mathrm{o}}$ and $C_{\mathrm{t}}$ are the initial and liquid-phase concentrations of paraquat solution at $t$ time $(\mathrm{mg} / \mathrm{L})$, respectively, $V$ is the volume of paraquat solution (ca. $2 \mathrm{~L}$ ), and $W$ is the mass of dry biochar used $(\mathrm{g})$. The effects of initial $\mathrm{pH}$ (i.e., $4.5,6.0,7.5$, and 9.0), initial paraquat concentration (0.5, $1.0,2.0,4.0$, and $6.0 \mathrm{mg} / \mathrm{L})$, and biochar dosage $(0.10$, $0.15,0.20,0.25$, and $0.30 \mathrm{~g} / \mathrm{L}$ ) on the adsorption kinetics were investigated under the initial agitation speed of $120 \mathrm{rpm}$ and temperature of $25^{\circ} \mathrm{C}$. In each experiment, the adsorption was carried out under the conditions where one parameter changed at a time, while the other parameters held constant. In order to evaluate the statistical significance of data in the kinetic experiments, each experiment was repeated using identical conditions, showing that the reproducibility of the measurements is within $5 \%$.

\section{Results and discussion}

Pseudo-second order reaction model

The rapid decrease in residual paraquat concentration within a short time scale implied a relatively strong cation-exchange interaction between the charged surface and paraquat ion. Many kinetic models, including first-order reversible reaction, pseudo-first-order reaction, and pseudo-second-order

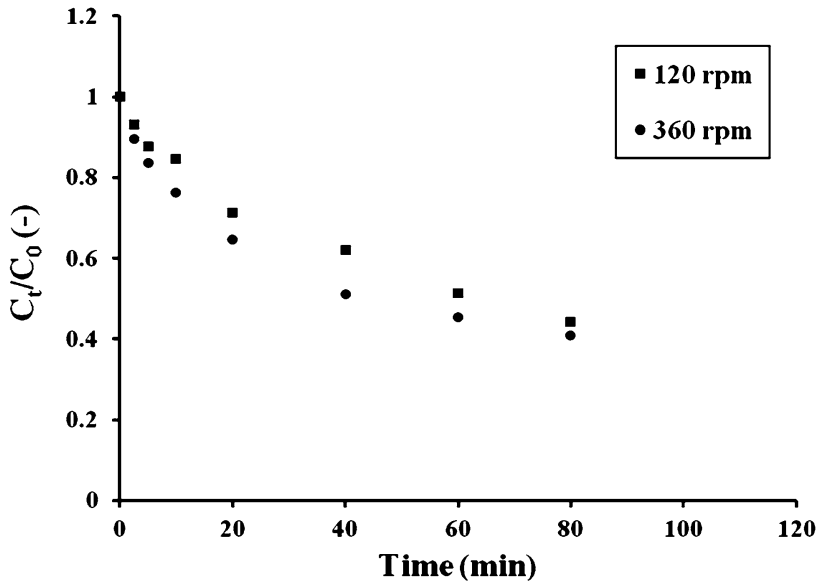

Fig. 2 Plots of variation of dimensionless paraquat concentration $\left(C_{t} /\right.$ $C_{0}$ ) versus time at 120 and $360 \mathrm{rpm}$ (adsorption conditions: initial $\mathrm{pH}=6.0, \quad$ initial concentration $=1.0 \mathrm{mg} / \mathrm{L}$, biochar dosage $=0.15 \mathrm{~g} / \mathrm{L}$, and temperature $=25^{\circ} \mathrm{C}$ )

reaction, have been used in liquid-phase adsorption and biosorption (Inglezakis and Poulopoulos 2006). In the present work, pseudo-second-order kinetic model was used to fit the experimental data and to describe the adsorption system due to its simple and better fitting for the fast decrease in residual paraquat concentration at a short-time scale (Kumar et al. 2012). In this model, the differential rate equation is the following form (Ho and McKay 1998):

$\mathrm{d} q_{\mathrm{t}} / \mathrm{d} t=k\left(q_{\mathrm{e}}-q_{\mathrm{t}}\right)^{2}$

where $k$ is the rate constant of sorption ( $\mathrm{g} / \mathrm{mg} \mathrm{min}), q_{\mathrm{e}}$ is the amount of paraquat ion adsorbed at equilibrium $(\mathrm{mg} / \mathrm{g}), q_{\mathrm{t}}$ is the amount of paraquat ion adsorbed at any time $t(\mathrm{mg} / \mathrm{g})$ as seen in Eq. (1). The linear form of the diffusion equation can be expressed as:

$t / q_{\mathrm{t}}=1 /\left(k \cdot q_{\mathrm{e}}^{2}\right)+\left(1 / q_{\mathrm{e}}\right) \cdot t$

Rate parameters, $k$ and $q_{\mathrm{e}}$, can be directly obtained from the intercept and slope of the plot of $t / q_{\mathrm{t}}$ against $t$. 
The equilibrium concentration (i.e., $C_{\mathrm{e}}$ ) can be further calculated using the mass balance concept as the value of $q_{\mathrm{e}}$ has been obtained from the fitting of Eq. (3); that is,

$C_{\mathrm{e}}=C_{\mathrm{o}}-\left(q_{\mathrm{e}} \cdot W / V\right)$

Effect of initial $\mathrm{pH}$

The effect of the initial $\mathrm{pH}$ (i.e., 4.5, 6.0, 7.5, and 9.0) on the paraquat uptake rate by the biochar adsorbent was shown in Fig. 3 , where the ratios $\left(C_{\mathrm{t}} / C_{\mathrm{o}}\right)$ of residual paraquat concentration to initial paraquat concentration as the adsorption time $(t)$ were denoted as discrete points and those obtained from the pseudo-second order model by solid lines. From the fitting data in Table 2, it was seen that the adsorption capacity (i.e., $q_{\mathrm{e}}$ ) of paraquat onto the biochar significantly increased when the $\mathrm{pH}$ of aqueous solution was changed from 4.5 to 7.5. From Fig. 3, the rate of adsorption decreased with time until it gradually approached a plateau due to the continuous decrease in the concentration driving force. On the other hand, the high fluctuation in the experimental data occurred at the initial stage (less than $10 \mathrm{~min}$ ), suggesting that the fitting data in Table 2 may be different from the observations in Fig. 3. Values of $k, q_{\mathrm{e}}$, correlation coefficient $\left(R^{2}\right)$, and $C_{\mathrm{e}}$ for the adsorption system, computed from the above equations, were listed in Table 2, from which it can be seen that the adsorption kinetics of paraquat on the biochar follows this model with the regression coefficients of higher than 0.94 for all the systems in this study. Clearly, the adsorption capacity (i.e., $q_{\mathrm{e}}$ ) increased as the initial $\mathrm{pH}$ ranged from 4.5 to 7.5 , and equilibrium concentration (i.e., $C_{\mathrm{e}}$ ) thus decreased. These observations indicated that as the $\mathrm{pH}$ increased, the adsorbed amount of cationic paraquat

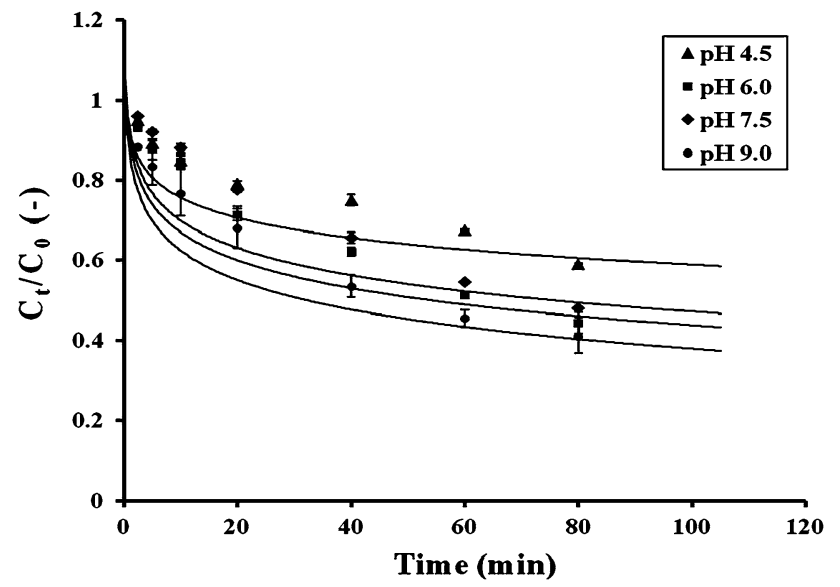

Fig. 3 Plots of variation of dimensionless paraquat concentration $\left(C_{\mathrm{t}} / C_{0}\right)$ versus time at various $\mathrm{pH}$ (adsorption conditions: initial concentration $=1.0 \mathrm{mg} / \mathrm{L}$, biochar dosage $=0.15 \mathrm{~g} / \mathrm{L}$, agitation speed $=120 \mathrm{rpm}$, and temperature $=25^{\circ} \mathrm{C}$; symbols experimental data, full lines calculated from Eq. (2) using the fitted values in Table 2)
Table 2 Kinetic parameters for paraquat adsorption onto the swinemanure-derived biochar at various initial $\mathrm{pH}$

\begin{tabular}{lllll}
\hline $\begin{array}{l}\text { Initial } \\
\mathrm{pH}\end{array}$ & $k(\mathrm{~g} / \mathrm{mg} \mathrm{min})$ & $q_{\mathrm{e}}(\mathrm{mg} / \mathrm{g})$ & $\begin{array}{l}\text { Correlation } \\
\text { coefficient }\end{array}$ & $C_{\mathrm{e}}(\mathrm{mg} / \mathrm{L})$ \\
\hline 4.5 & 0.0151 & 2.8185 & 0.9403 & 0.5772 \\
6.0 & 0.0071 & 4.6707 & 0.9641 & 0.2994 \\
7.5 & 0.0031 & 5.3191 & 0.9750 & 0.2021 \\
9.0 & 0.0115 & 4.7801 & 0.9841 & 0.2830 \\
\hline
\end{tabular}

Adsorption conditions: initial paraquat concentration $=1 \mathrm{mg} / \mathrm{L}$, biochar dosage $=0.15 \mathrm{~g} / \mathrm{L}, \quad$ agitation $\quad$ speed $=120 \mathrm{rpm}, \quad$ and temperature $=25{ }^{\circ} \mathrm{C}$

increased in response to the increasing number of negatively charged sites that are available due to the loss of $\mathrm{H}^{+}$ from the surface (Tsai et al. 2003b). As seen in Table 1 and Fig. 1, the ash composition in the swine-manure-derived biochar could contain some clay minerals such as calcite $\left(\mathrm{CaCO}_{3}\right)$ and whitlockite $\left[(\mathrm{Ca} \cdot \mathrm{Mg})_{3}\left(\mathrm{PO}_{4}\right)_{2}\right] \quad(\mathrm{Cao}$ and Harris 2010; Yao et al. 2011).

In addition, it was found that a slight decrease in the adsorption capacity (i.e., $q_{e}$ ) occurred at initial $\mathrm{pH}$ ranging from 7.5 to 9.0 . Based on the $\mathrm{pH}$ measurement determined in a mixture of $5 \mathrm{~g}$ biochar and $10 \mathrm{~mL}$ de-ionized water following $1 \mathrm{~h}$ equilibrium (Cao and Harris 2010), the $\mathrm{pH}$ value in the biochar is about 7.6, showing that the adsorbent exhibited an alkaline nature. As a result, the charge sign on the surface of the biochar should be liable to be positive in the alkaline solution. Therefore, the extent of cationic paraquat adsorbed on the adsorbent tended to decrease with the increase of $\mathrm{pH}$ values from 7.5 to 9.0, which may be attributed to the electrostatic repulsion between the positively charged surface and the positively charged adsorbate molecule.

\section{Effect of initial paraquat concentration}

The effect of the initial paraquat concentration (i.e., $0.5-6.0 \mathrm{mg} / \mathrm{L}$ ) on the intake rate by the swine-manurederived biochar at adsorbent dosage of $0.15 \mathrm{~g} / \mathrm{L}$, initial $\mathrm{pH}$ of 6.0 , mixing speed of $120 \mathrm{rpm}$, and temperature of $25^{\circ} \mathrm{C}$ was shown in Fig. 4, where the experimental data were shown as discrete points and those obtained from the model by solid lines. It is evident from Fig. 4 that the adsorption rate also decreased with time until it gradually approached a plateau due to the continuous decrease in the concentration driving force. The kinetic data obtained from batch studies have been analyzed using the pseudo-second order model. The values of $k, q_{\mathrm{e}}$, correlation coefficient $\left(R^{2}\right)$, and $C_{\mathrm{e}}$ for the paraquat adsorption system, computed from Eq. (2), were listed in Table 3, from which it will be seen that the kinetics of paraquat adsorption onto the biochar still follows this model with the regression coefficients of 


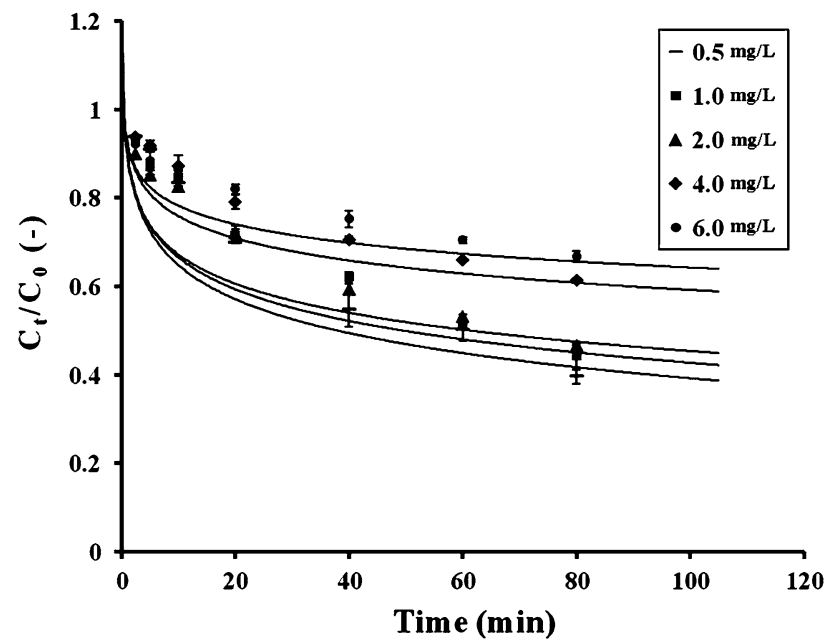

Fig. 4 Plots of variation of dimensionless paraquat concentration $\left(C_{\mathrm{t}} / C_{0}\right)$ versus time at various initial concentrations (adsorption conditions: initial $\mathrm{pH}=6.0$, biochar dosage $=0.15 \mathrm{~g} / \mathrm{L}$, agitation speed $=$ $120 \mathrm{rpm}$, and temperature $=25^{\circ} \mathrm{C}$; symbols experimental data, full lines calculated from Eq. (2) using the fitted values in Table 3)

higher than 0.96 for all the system in this study. Clearly, the adsorption capacity (i.e., $q_{\mathrm{e}}$ ) increased as the initial paraquat concentration and equilibrium concentration (i.e., $C_{\mathrm{e}}$ ) increased, which is also consistent with the paraquat adsorption isotherms by activated bleaching earth in our previous studies (Tsai et al. 2002a, b, 2004). Similar results were observed by Hamadi et al. (2004) for the adsorption system of paraquat onto the activated carbon derived from used tire. It was found that the equilibrium adsorption capacity of paraquat onto tire-derived activated carbon was about $7.3 \mathrm{mg} / \mathrm{g}$ under the conditions at initial paraquat concentration of $40 \mathrm{mg} / \mathrm{L}$, initial $\mathrm{pH}$ of 7.0 , and temperature of $25^{\circ} \mathrm{C}$.

\section{Effect of biochar dosage}

The effect of varying the biochar dosages (i.e., $0.10-0.30 \mathrm{~g} / \mathrm{L}$ ) on paraquat adsorption at the initial paraquat concentration of $1.0 \mathrm{mg} / \mathrm{L}$, initial $\mathrm{pH}$ of 6.0 , mixing speed of $120 \mathrm{rpm}$, and temperature of $25^{\circ} \mathrm{C}$ was shown in Fig. 5. The values of parameters for the adsorption system have been obtained and listed in Table 4. It is also evident from Fig. 5 that the correlation between the experimental and theoretical results is also good from the values of correlation coefficient $(>0.96)$. It was found that the residual equilibrium concentration in the solution was on the decrease as the adsorbent dosage increased. This implied that the number of adsorption sites (or total surface area) increased in parallel with the increase of adsorbent dosage. However, the adsorption capacity (i.e., $q_{\mathrm{e}}$ ) of the swine-manure-derived biochar decreased as its mass
Table 3 Kinetic parameters for paraquat adsorption onto the swinemanure-derived biochar at various initial paraquat concentrations

\begin{tabular}{llrll}
\hline $\begin{array}{l}\text { Initial paraquat } \\
\text { conc }(\mathrm{mg} / \mathrm{L})\end{array}$ & $\begin{array}{l}k(\mathrm{~g} / \\
\mathrm{mg} \min )\end{array}$ & \multicolumn{1}{l}{$\begin{array}{l}q_{\mathrm{e}}(\mathrm{mg} / \\
\mathrm{g})\end{array}$} & $\begin{array}{l}\text { Correlation } \\
\text { coefficient }\end{array}$ & $\begin{array}{l}C_{\mathrm{e}} \\
(\mathrm{mg} / \mathrm{L})\end{array}$ \\
\hline 0.5 & 0.0089 & 2.8531 & 0.9794 & 0.0720 \\
1.0 & 0.0071 & 4.6707 & 0.9641 & 0.2994 \\
2.0 & 0.0058 & 8.2169 & 0.9701 & 0.7675 \\
4.0 & 0.0034 & 12.4378 & 0.9831 & 2.1343 \\
6.0 & 0.0041 & 14.7929 & 0.9733 & 3.7811 \\
\hline
\end{tabular}

Adsorption conditions: biochar dosage $=0.15 \mathrm{~g} / \mathrm{L}$, initial $\mathrm{pH}=6.0$, agitation speed $=120 \mathrm{rpm}$, and temperature $=25^{\circ} \mathrm{C}$

increased. This was to be reasonably expected because the monolayer coverage of paraquat on the outer interface of biochar dominated the adsorption system at a fixed paraquat amount from the time-rate adsorption curves, even if increasing the biochar adsorbent dosage provided a more external surface area and, therefore, the total number of adsorption sites increased. This would further lead to a suggestion that higher initial paraquat concentrations should be tested in conjunction with appropriate adsorbent dosage to obtain the optimal adsorbent dosage.

\section{Adsorption comparison}

In order to obtain the preliminary information on the removal efficiencies of paraquat from aqueous solution using swine-manure-derived biochar in comparison with commercial activated carbon (i.e., BPL), their adsorption characteristics carried out at the adsorbent loading of $0.15 \mathrm{~g} / \mathrm{L}$, initial concentration of $4.0 \mathrm{mg} / \mathrm{L}$, initial $\mathrm{pH}$ of 6.2 , mixing speed of $120 \mathrm{rpm}$, and temperature of $25^{\circ} \mathrm{C}$

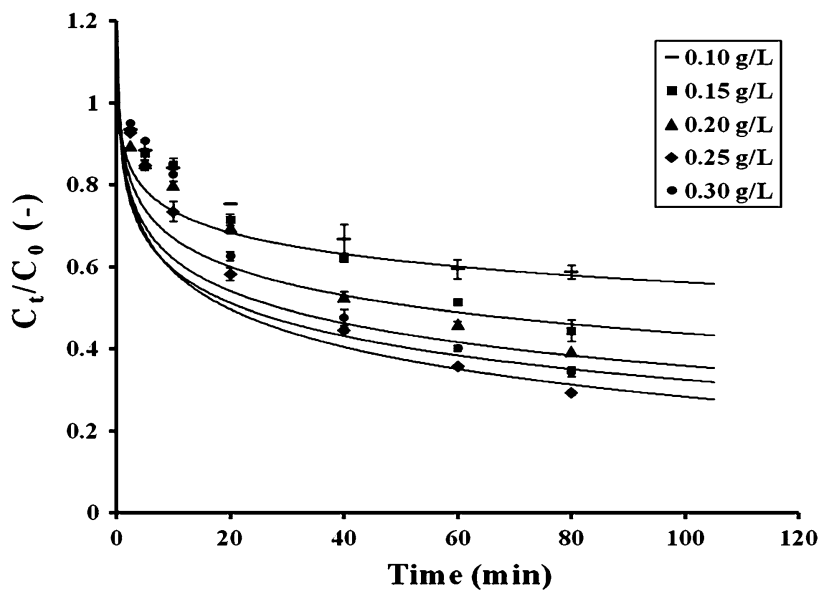

Fig. 5 Plots of variation of dimensionless paraquat concentration $\left(C_{\mathrm{t}} / C_{0}\right)$ versus time at various biochar dosages (adsorption conditions: initial $\mathrm{pH}=6.0$, initial concentration $=1.0 \mathrm{mg} / \mathrm{L}$, agitation speed $=120 \mathrm{rpm}$, and temperature $=25^{\circ} \mathrm{C}$; symbols experimental data, full lines calculated from Eq. (2) using the fitted values in Table 4) 
Table 4 Kinetic parameters for paraquat adsorption onto the swinemanure-derived biochar at various biochar dosages

\begin{tabular}{lllll}
\hline $\begin{array}{l}\text { Biochar } \\
\text { dosage }(\mathrm{g} / \mathrm{L})\end{array}$ & $k(\mathrm{~g} / \mathrm{mg} \mathrm{min})$ & $q_{\mathrm{e}}(\mathrm{mg} / \mathrm{g})$ & $\begin{array}{l}\text { Correlation } \\
\text { coefficient }\end{array}$ & $C_{\mathrm{e}}(\mathrm{mg} / \mathrm{L})$ \\
\hline 0.10 & 0.0096 & 5.2687 & 0.9925 & 0.4731 \\
0.15 & 0.0071 & 4.6707 & 0.9641 & 0.2994 \\
0.20 & 0.0113 & 3.7936 & 0.9741 & 0.2413 \\
0.25 & 0.0108 & 3.4542 & 0.9966 & 0.1365 \\
0.30 & 0.0062 & 3.2541 & 0.9609 & 0.0238 \\
\hline
\end{tabular}

Adsorption conditions: initial paraquat concentration $=1 \mathrm{mg} / \mathrm{L}$, initial $\mathrm{pH}=6.0$, agitation speed $=120 \mathrm{rpm}$, and temperature $=25^{\circ} \mathrm{C}$

were investigated in this work.. Based on the data fitted by the pseudo-second order model, it showed that the fitting value of $q_{\mathrm{e}}$ for commercial adsorbent only appeared to be about $2.0 \mathrm{mg} / \mathrm{g}$ in the adsorption system $\left(R^{2}=0.9756\right)$. Obviously, the fitting adsorption capacity of paraquat onto the carbon adsorbent was slightly lower than that (i.e., about $4.7 \mathrm{mg} / \mathrm{g}$ ) of swine-manure-derived biochar, showing that activated carbon will be less effective than biomass-derived adsorbent for the adsorption of paraquat. However, the adsorption capacities are not in proportion to their pore properties $\left(1,000\right.$ vs. $6 \mathrm{~m}^{2} / \mathrm{g}$ based on BET surface area, seen in Table 1). Further, it is well known that the unique surface property of activated carbon, in contrast to the other adsorbents (e.g., clay) (Tsai et al. 2004), is that its surface is nonpolar. It implied that the pore properties (e.g., BET surface area) in the case of the adsorbent are not determining factors for the removal of cationic paraquat.

\section{Conclusion}

The use of biochar from separated swine manure for the adsorptive removal of paraquat from aqueous solution has been examined. The following conclusions can be drawn:

1. Initially, the adsorption rate of paraquat onto the porous biochar adsorbent is rapid. This is then followed by a slower rate and gradually approaches a plateau.

2. The adsorption kinetics can be described by the pseudo-second order model equation, which is consistent with those of the similar adsorption systems, e.g., activated carbon-paraquat.

3. The effects of the initial $\mathrm{pH}$, paraquat concentration, and biochar dosage on the adsorption rate at $25{ }^{\circ} \mathrm{C}$ were found to be of considerable significance in the ion exchange process, which is in line with those of the clay-paraquat systems.

4. The above results suggest that the swine-manurederived biochar can be used as a low-cost adsorbent for the removal of cationic pesticides (e.g., paraquat) from an aqueous environment such as groundwater and soil water.

Acknowledgments The authors wish to acknowledge all who supported this work.

\section{References}

Blaschek HP, Ezeji TC, Scheffran J (2010) Biofuels from agricultural wastes and byproducts: an introduction. In: Blaschek HP, Ezeji TC, Scheffran J (eds) Biofuels from agricultural wastes and byproducts. Wiley, Ames, pp 3-10

Brady M, McGay G (1996) Characterization of adsorbents. In: McKay G (ed) Use of adsorbents for the removal of pollutants from wastewaters. CRC Press, Boca Raton, pp 39-57

Cao X, Harris W (2010) Properties of dairy-manure-derived biochar pertinent to its potential use in remediation. Bioresour Technol 101:5222-5228

de Keizer A (1990) Adsorption of paraquat ions on clay minerals: electrophoresis of clay particles. Progr Colloid Polym Sci $83: 118-126$

Draoui K, Denoyel R, Chgoura M, Rouquerol J (1999) Adsorption of paraquat on minerals: a thermodynamic study. J Therm Anal Cal 58:597-606

Fernandez M, Ibanez M, Pico Y, Manes J (1998) Spatial and temporal trends of paraquat, diquat, and diffenzoquat contamination in water from marsh areas of the Valencian community (Spain). Arch Environ Contam Toxicol 35:377-384

Hamadi NK, Swaminathan S, Chen XD (2004) Adsorption of paraquat dichloride from aqueous solution by activated carbon derived from used tires. J Hazard Mater B11:133-141

He B, Zhang Y, Funk T, Riskowski G, Yin Y (2000a) Operating temperature and retention time effects on the thermochemical conversion process of swine manure. Trans ASAE 43:1821-1826

He B, Zhang Y, Yin Y, Funk T, Riskowski G (2000b) Thermochemical conversion of swine manure: an alternative process for waste treatment and renewable energy production. Trans ASAE 43:1827-1833

Ho YS, McKay G (1998) Kinetic models for the sorption of dye from aqueous solution by wood. Trans IChemE 76(B):183-191

Inglezakis VJ, Poulopoulos SG (2006) Adsorption, ion exchange and catalysis - design of operations and environmental applications. Elsevier, Amsterdam

IPCC (2006) 2006- IPCC guidelines for national greenhouse gases inventories. Intergovernmental Panel on Climate Change, Geneva

Khan SK (1980) Pesticides in the soil environment. Elsevier, Amsterdam

Kumar R, Jain SK, Misra RK, Kachchwaha M, Khatri PK (2012) Aqueous heavy metals removal by adsorption on $\beta$-diketonefunctionalized styrene-divinylbenzene copolymeric resin. Int $\mathbf{J}$ Environ Sci Technol 9:79-84

Lehannes J, Joseph S (2009) Biochar for environmental management: an introduction. In: Lehannes J, Joseph S (eds) Biochar for environmental management: science and technology. Earthscan, London, pp 1-12

Lock EA, Wilks MF (2010) Paraquat. In: Krieger R (ed) Hayes' handbook of pesticide toxicology. Elsevier, Amsterdam, pp 1771-1827

MacCarthy P, Djebbar KK (1986) Removal of paraquat, diquat, and amitrole from aqueous solution by chemically modified peat. J Environ Qual 15:103-107 
Parkash S (1974) Adsorption of cationic pesticides (diquat and paraquat) from aqueous solution by activated carbon. Carbon $12: 483-491$

Priyadarsan S, Annamalai K, Sweeten JM, Mukhtar S, Holtzapple MT (2004) Fixed-bed gasification of feedlot manure and poultry litter biomass. Trans ASAE 47:1689-1696

Qian Q, Machida M, Tatsumoto H (2008) Textural and surface chemical characteristics of activated carbons prepared from cattle manure compost. Waste Manag 28:1064-1071

Ritter L, Solomon K, Sibley P, Hall K, Keen P, Mattu G, Linton B (2002) Sources, pathways, and relative risks of contaminants in surface water and groundwater: a perspective prepared for the walkerton inquiry. J Toxicol Environ Health (A) 65:1142

Ro KS, Cantrell KB, Elliott DC, Hunt PG (2007) Catalytic wet gasification of municipal and animal wastes. Ind Eng Chem Res 46:8839-8845

Ro KS, Cantrell KB, Hunt PG, Ducey TF, Vanotti MB, Szogi AA (2009) Thermochemical conversion of livestock wastes: carbonization of swine solids. Bioresour Technol 100:5466-5471

Ro KS, Cantrell KB, Hunt PG (2010) High-temperature pyrolysis of blended animal manures for producing renewable energy and value-added biochar. Ind Eng Chem Res 49:1012510131

Sannino F, Iorio M, De Martino A, Pucci M, Brown CD, Capasso R (2008) Remediation of waters contaminated with ionic herbicides by sorption on polymerin. Water Res 42:643-652
Tsai WT, Chang CY, Lee SL (1997) The preparation characterization of activated carbons from corn cob. Carbon 35:1198-1200

Tsai WT, Chang CY, Lee SL (1998) A low cost adsorbent from agricultural waste corn cob by zinc chloride activation. Bioresour Technol 64:211-217

Tsai WT, Chen HP, Yang JM (2002a) Adsorption of paraquat on the physically activated bleaching earth waste from soybean oil processing plant. J Environ Sci Health B37:453-463

Tsai WT, Hsieh MF, Sun HF, Chien SF, Chen HP (2002b) Adsorption of paraquat onto activated bleaching earth. Bull Environ Contam Toxicol 69:189-194

Tsai WT, Lai CW, Hsien KJ (2003a) Effect of particle size of activated clay on the adsorption of paraquat from aqueous solution. J Colloid Interface Sci 263:29-34

Tsai WT, Lai CW, Hsien KJ (2003b) The Effect of pH and salinity on kinetics of paraquat sorption onto activated clay. Colloid Surf A 224:99-105

Tsai WT, Lai CW, Hsien KJ (2004) Adsorption kinetics of herbicide paraquat from aqueous solution onto activated bleaching earth. Chemosphere 55:829-837

Yao Y, Guo B, Inyang M, Zimmerman AR, Cao X, Pullammanappallil P, Yang L (2011) Biochar derived from anaerobically digested sugar beet tailings: characterization and phosphate removal potential. Bioresour Technol 102:6273-6278

Zhang SY, Hong RY, Cao JP, Takarada T (2009) Influence of manure types and pyrolysis conditions on the oxidation behavior of manure char. Bioresour Technol 100:4278-4283 